ARTIKEL PENELITIAN

\title{
PENGARUH TEKHNIK BABY SPA TERHADAP PERKEMBANGAN MOTORIK DAN KENAIKAN BERAT BADAN BAYI
}

\author{
Vita Triani Adi Puteri ${ }^{1)}$, Syarief Taufik²), Melyana Nurul ${ }^{3)}$ \\ ${ }^{1)}$ Magister Sains Terapan Kesehatan, Universitas Diponegoro Semarang \\ ${ }^{2)}$ Doktoral Kesehatan, Universitas Diponegoro Semarang \\ ${ }^{3)}$ Doktoral Kesehatan, Poltekes Kemenkes Semarang \\ Email : vita_puteri@ymail.com
}

\begin{abstract}
Background: Baby Spa is a series of stimulation of growth and development of children by combining baby gym services, baby swimming and baby massage. In the Kedungmundu District Health Center, it was found that the incidence of infants who had poor nutrition were 6 babies, malnutrition were 3 infants and those who suffered from growth disorder were 15 infants. Objective: This research was aimed to find out the influence of baby spa techniques on motor development and increase in baby's weight. Method: this study used Quasi Experiment method with Pre and Post test with control group design, data analysis used Dependent T Test and Independent T test. Results: There were differences in motor development before and after the treatment, it obtained $p$ Value of 0.001 in the treatment group and $p$ value of 0.041 in the control group. There were differences in infant weight gain before and after baby spa (P Value 0,000$)$ in the treatment group and no difference increase in baby's weight (P Value 0.061) in the control group, there is the influence of giving Baby Spa techniques and baby massage to baby's motor development in the two groups (P Value 0.021), there is the influence of Baby Spa techniques and baby massage on baby's weight in the second group ( $\mathrm{P}$ Value 0.04). Conclusions: There are differences in motor development and increase of baby weight in both groups, and there are effects of Baby Spa techniques and baby massage on motor development and baby's weight increase in baby aged 4-12 months in each group.
\end{abstract}

Keywords : Baby Spa, Motor Development, and increasing of baby’s weight

\begin{abstract}
Baby spa merupakan rangkaian stimulasi tumbuh kembang anak dengan memadukan layanan senam bayi (baby gym), berenang (baby swim) dan pijat bayi (baby massage). Hasil survey pendahuluan yang dilakukan di puskesmas kedungmundu semarang didapatkan hasil bayi yang mengalami kurang gizi sebanyak 6 bayi, gizi buruk sebanyak 3 bayi dan yang mengalami keterlambatan perkembangan motorik sebanyak 15 bayi. The Aim Of Research : Mengetahui pengaruh tekhnik baby spa terhadap perkembangan motorik dan kenaikan berat badan bayi. Research Methode : Jenis penelitian menggunakan quasi eksperimental design dengan rancangan penelitian menggunakan pretest - posttest with control group design. Sampel yang diambil dalam penelitian ini adalah bayi usia $4-12$ bulan yang berjumlah 30 bayi. Analisa data menggunakan dependent sample $t$ - test. The Result : Ada pengaruh pemberian teknik baby spa pada kelompok perlakuan dan pijat bayi pada kelompok kontrol terhadap perkembangan motorik bayi dengan hasil nilai $\mathrm{P}$ value 0,021 dan ada pengaruh pemberian teknik baby spa pada kelompok perlakuan dan pijat bayi pada kelompok control terhadap kenaikan berat badan bayi dengan hasil nilai $\mathrm{P}$ value 0,04 . Conclusion: Ada pengaruh teknik baby spa terhadap perkembangan motorik dan kenaikan berat badan bayi.
\end{abstract}

Keywords : Teknik Baby Spa, Perkembangan motorik bayi, Kenaikan berat badan bayi

PENDAHULUAN

$\begin{array}{rrrr}\text { Masa } & \text { bayi adalah } & \text { masa } \\ \text { keemasan } & \text { sekaligus } & \text { masa } & \text { kritis }\end{array}$

perkembangan. Dikatakan masa kritis karena pada masa ini bayi sangat peka terhadap lingkungan dan dikatakan 
masa keemasan karena masa bayi berlangsung sangat singkat dan tidak dapat diulang kembali. Hal ini yang membedakan anak dengan dewasa. Anak menunjukkan ciri-ciri pertumbuhan dan perkembangan yang sesuai dengan usianya (Azis, 2008). Badan Pusat Statistik Kesehatan Bayi di Jawa Tengah pada tahun 2007 mendapatkan hasil bahwa prevalensi gangguan tumbuh kembang menempati prevalensi tertinggi setelah masalah gizi (Depkes RI, 2009). Perkembangan dan pertumbuhan bayi dipengaruhi oleh tiga faktor, yaitu faktor yang berhubungan dengan genetik dan jenis kelamin, faktor hormonal, dan faktor lingkungan dari bayi sejak dalam kandungan dan bayi sesudah lahir, diantaranya seperti asupan gizi ibu saat hamil, riwayat persalinan, gizi yang diberikan bagi bayi setelah lahir, stimulasi lingkungan sekitar, trauma, penyakit dan lain-lain (Dasuki, 2019) Stimulus taktil yang dapat diberikan salah satunya bisa dilakukan dengan melakukan baby spa kepada bayi, karena dengan baby spa tersebut dapat merangsang otot-otot, tulang dan sistem organ untuk berfungsi secara maksimal (Dasuki, 2019). Baby spa merupakan rangkaian stimulasi tumbuh kembang anak dengan memadukan layanan senam bayi (baby gym), berenang (baby swim), pijat bayi (baby massage). Bayi yang diberikan baby spa tentu akan berbeda tumbuh kembangnya dengan tumbuh kembang bayi yang tidak diberi baby spa. Hal ini dikarenakan rangkaian baby spa bertujuan merangsang saraf sensoris dan motoris bayi lebih dini dengan stimulusstimulus-stimulus tertentu sehingga bayi tumbuh aktif serta lebih optimal baik secara fisik maupun mentalnya (momnjo, 2013). Penelitian Unggul Budi (2015) tentang pengaruh baby spa terhadap perkembangan motorik kasar pada bayi usia 3-6 bulan menunjukkan ada pengaruh baby spa terhadap perkembangan motorik kasar bayi usia 3-6 bulan yang dipantau melalui DDST (Denver Development Screening Test). Penelitian Alif Frani (2014) tentang hubungan frekuensi baby spa dengan berat badan pada bayi usia $7-12$ bulan menunjukkan ada hubungan yang signifikan pada frekuensi baby spa terhadap berat badan pada bayi usia 7 12 bulan.

Perumusan masalah dalam penelitian ini adalah bagaimanakah pengaruh tekhnik baby spa terhadap perkembangan motorik dan kenaikan berat badan bayi di wilayah kerja puskesmas 
kedungmundu semarang? Sedangkan tujuan dalam penelitian ini adalah untuk mengetahui pengaruh tekhnik baby spa terhadap perkembangan motorik dan kenaikan berat badan bayi di wilayah kerja puskesmas kedungmundu semarang.

\section{METODE PENELITIAN}

Jenis penelitian ini menggunakan quasi eksperimental design dengan rancangan penelitian menggunakan pre - test post - test with control group design. Populasi yang digunakan dalam penelitian ini adalah bayi usia 4-12 bulan sebanyak 30 bayi sedangkan sample yang digunakan dalam penelitian ini adalah sebanyak 15 bayi untuk kelompok perlakuan dan 15 bayi untuk kelompok kontrol. Teknik sample yang digunakan dalam penelitian ini adalah teknik total sampling. Variabel independen dalam penelitian ini adalah teknik baby spa yang dilakukan pada kelompok perlakuan dan treatment pijat bayi pada kelompok kontrol, sedangkan untuk variable dependent dalam penelitian ini adalah perkembangan motorik bayi yang diukur dengan instrument lembar KPSP dan kenaikan berat badan bayi yang diukur menggunakan instrument timbangan bayi dan dipantau menggunakan lembar
KMS. Analisa data dalam penelitian ini menggunakan dependent sample $\mathrm{t}$ - test. Hipotesa dalam penelitian ini adalah ada pengaruh tekhnik baby spa terhadap perkembangan motorik dan kenaikan berat badan bayi.

\section{HASIL DAN PEMBAHASAN}

A. Perkembangan Motorik Bayi

Tabel 1. Perkembangan Motorik

Bayi Pre dan Post Intervensi Pada

Kelompok Perlakuan dan Kelompok Kontrol

\begin{tabular}{lccc}
\hline Kelompok & Perlakuan & Kontrol & $\begin{array}{c}P \\
\text { Value }\end{array}$ \\
\hline Pre test & 8,13 & 8,20 & 0 \\
\cline { 1 - 3 } Post test & 9,07 & 8,47 & 022 \\
\cline { 1 - 3 }$P$ Value & 0,001 & 0,046 & \\
\hline
\end{tabular}

Berdasarkan tabel penelitian di atas diperoleh hasil bahwa perkembangan motorik bayi sebelum dan sesudah dilakukan baby spa pada kelompok perlakukan nilai $p$ value 0,001. Sedangkan pada kelompok kontrol dengan intervensi sebelum dan sesudah dilakukan pijat bayi didapatkan nilai $P$ Value 0,046 . Sedangkan hasil post test untuk kelompok perlakuan dan kelompok kontrol nilai $P$ Value 0,022 yang berarti perbedaan hasil uji beda pada ke dua kelompok menunjukkan masingmasing kelompok ada perbedaan sebelum dan sesudah diberikan intervensi dan ada pengaruh pemberian 
intervensi pada kedua kelompok. Hal ini dikarenakan intervensi baby spa pada kelompok perlakuan dan massage pada kelompok kontrol, sama-sama mampu menstimulasi perkembangan pada bayi.

B. Kenaikan Berat Badan Bayi

Tabel 2. Kenaikan Berat Badan Bayi Pre dan Post Intervensi Pada Kelompok Perlakuan dan Kelompok Kontrol

Berdasarkan tabel penelitian di atas diperoleh hasil bahwa kenaikan berat badan bayi sebelum dan sesudah dilakukan baby spa pada kelompok perlakukan didapatkan nilai $P$ Value 0,000. Sedangkan pada kelompok kontrol dengan intervensi sebelum dan sesudah dilakukan pijat bayi didapatkan nilai $P$ Value 0,061. Sedangkan hasil post test untuk kelompok perlakuan dan kelompok kontrol didapatkan nilai $P$ Value 0,04. Perbedaan hasil uji beda pada ke dua kelompok menunjukkan setelah pemberian treatment baby spa ada perbedaan kenaikan berat badan bayi sebelum dan sesudah dilakukan baby spa pada kelompok perlakuan sedangkan setelah treatment pijat bayi tidak ada perbedaan kenaikan berat badan bayi sebelum dan sesudah dilakukan pijat bayi pada kelompok kontrol dan pada uji pengaruh kedua kelompok didapatkan hasil ada pengaruh pemberian intervensi pada kedua kelompok. Hal ini dikarenakan intervensi baby spa pada kelompok perlakuan dan massage pada kelompok kontrol, sama-sama mempunyai manfaat yang sama untuk meningkatkan berat badan bayi.

\begin{tabular}{lccc}
\hline Kelompok & Perlakuan & Kontrol & $\begin{array}{c}P \\
\text { Value }\end{array}$ \\
\hline Pre test & 7,33 & 9,11 & \\
\cline { 1 - 3 } Post test & 7,77 & 9,19 & 04 \\
\cline { 1 - 2 }$P$ Value & 0,000 & 0,061 & \\
\hline
\end{tabular}

\section{SIMPULAN}

1. Ada perbedaan perkembangan motorik sebelum dan sesudah diberikan baby spa pada kelompok perlakuan.

2. Ada perbedaan perkembangan motorik sebelum dan sesudah diberikan pijat bayi pada kelompok kontrol.

3. Ada perbedaan kenaikan berat badan bayi sebelum dan sesudah diberikan baby spa pada kelompok perlakukan.

4. Tidak ada perbedaan kenaikan berat badan bayi sebelum dan sesudah diberikan pijat bayi pada kelompok kontrol.

5. Ada perbedaan perkembangan motorik pada kelompok 
perlakuan dan kelompok kontrol setelah diberikan intervensi.

6. Ada perbedaan kenaikan berat badan bayi pada kelompok perlakuan dan kelompok kontrol setelah diberikan intervensi.

Saran :

1. Diharapkan kepada orangtua bayi agar selalu berupaya mengoptimalkan pertumbuhan dan perkembangan bayinya semaksimal mungkin dengan berbagai usaha yang salah satunya bisa diupayakan dengan rutin melakukan baby spa kepada bayi karena dengan sering melakukan baby spa banyak sekali manfaat yang akan didapatkan oleh bayi.

2. Diharapkan peneliti selanjutnya dapat mengembangkan penelitian lanjutan dengan variabel yang berbeda sehingga diharapkan masyarakat dapat benar-benar mengetahui secara pasti manfaat dari teknik baby spa terhadap bayi

\section{UCAPAN TERIMA KASIH}

Puji syukur peneliti panjatkan kehadirat Allah SWT karena berkat limpahan rahmat dan hidayahnya akhirnya peneliti dapat menyelesaikan tesis ini dengan lancar. Terima kasih yang sebesar-besarnya peneliti haturkan khususnya kepada dosen pembimbing yang sudah dengan sabar memberikan arahan dan bimbingannya selama proses penyusunan tesis ini sehingga pada akhirnya tesis ini dapat terselesaikan dengan baik. Ucapan terima kasih juga peneliti ucapkan khususnya kepada kedua orang tua, suami tercinta yang selalu mendukung dan membantu dalam proses penyusunan tesis ini, anak-anak $\mathrm{ku}$ tersayang yang selalu menjadi penyemangat hidupku, segenap keluarga besarku dan semua pihak yang sudah membantu dan mendukung dalam penyelesaian tesis ini yang tidak bisa peneliti sebutkan satu persatu.

\section{DAFTAR PUSTAKA}

Alimul, Azis. 2008. Asuhan Neonatus, bayi dan balita. Jakarta : EGC

Depkes RI. 2009. Sistem Kesehatan Nasional. Jakarta

Dasuki. Data Pijat Bayi. http://www.google.com.diakses 2 Februari 2019

www. Momnjo.com. 2013

Budi, Unggul dkk. 2015. Pengaruh Baby Spa Terhadap Perkembangan Motorik Kasar Pada Bayi Usia 3 6 Bulan Di Mom'me Organic baby And Kids Spa Kota Semarang. 
Mahakam Midwifery Journal, Vol 2, No. 5, Mei 2019 : 324-329

Semarang : Prodi DIII Kebidanan UNIMUS

Frani, Alif. 2014. Hubungan Frekuensi Baby Spa Dengan Berat Badan
Pada Bayi Usia 7-12 Bulan Di Klinik Baby Spa Ananda Ambarawa 